Гусейнов Г.-Р.А.-К. Лексические особенности кизлярского говора терского диалекта кумыкского языка в ареальном и историко-этимологическом контексте позднесредневековой эпохи

УДК $811.351 .14 / 16$

DOI: 10.21779/2542-0313-2018-33-3-61-66

\title{
Г.-Р.А.-К. Гусейнов
}

\section{Лексические особенности кизлярского говора терского диалекта кумыкского языка в ареальном и историко-этимологическом контексте позднесредневековой эпохи}

\author{
Дагестанский государственный университет; Россия, 367001, 2. Махачкала, \\ ул. М. Гаджиева, 43a; garun48@mail.ru
}

Статья продолжает цикл исследований автора последних лет, посвященных введению в научный тюркологический оборот материалов изолированного (селения Кизляр, Предгорное и Малый Малгобек Моздокского района Республики Северная Осетия - Алания) кизлярского говора терского диалекта кумыкского языка. Он был практически не изучен до последнего времени, и основная цель публикации - рассмотрение лексических особенностей данного говора в широком ареальном и историко-этимологическом контексте. В результате произведенного анализа были приведены дополнительные лингвистические и исторические аргументы, которые еще раз указывают на более обширные западные ареальные пределы распространения кумыкского языка в рассматриваемую эпоху. Их интерпретация в других кумыкских говорах, а также привлечение новейших исторических данных позволили, во-первых, еще раз уточнить время миграции носителей другого соседнего восточного (брагунского) терского кумыкского говора, локализуемого в Чечне, в южную кумыкскую историческую область Кайтаг; во-вторых - предположить более раннее возникновение некоторых рассмотренных при этом лексических особенностей.

Ключевые слова: кумыкский, карачаево-балкарский, ногайский, кизлярский, брагунский, говор, диалект, ареальный и историко-этимологический контекст.

Говоря об истории рассматриваемого вопроса, следует отметить его неизученность еще полстолетия назад до выхода из печати известной монографии И.А. Керимова. В ней был кратко, в основных чертах описан и терский диалект кумыкского языка, но при этом не упоминался его кизлярский говор, особенности которого характеризуются лишь в отношении отдельных лексических фактов (ок. 150 единиц) периферийного характера, неизвестных кумыкскому литературному языку (значительную его часть составляют русизмы) [10, с. 125-126]. В дальнейшем той же традиции следовал Ж.М. Хангишиев [16, с. 78-79], который, говоря о терском диалекте, приводит в своем кратком курсе кумыкской диалектологии около 120 лексических единиц того же порядка, присущих говору с. Кизляр.

Правомочность выделения кизлярского говора в дальнейшем априорно поддерживается тем, что увидело свет издание, посвященное второму говору терского кумыкского диалекта - бораганскому (брагунскому) [12]. Затем защищается докторская диссертация того же автора, в которой говорится об особенностях фонетических систем брагунского и кизлярского говоров наряду с прочими кумыкскими говорами [13, с. 13]. Однако и в последних публикациях других исследователей кумыкских диалектов, в т. ч. по лексике, не были учтены или рассмотрены данные как кизлярского, так и брагунского говоров [3, 14]. 
Гусейнов Г.-Р.А.-К. Лексические особенности кизлярского говора терского диалекта кумыкского языка в ареальном и историко-этимологическом контексте позднесредневековой эпохи

Цель же настоящего исследования - продолжить и дополнить в широком ареальном и историко-этимологическом контексте цикл исследований автора последних нескольких лет, посвященных изучению рассматриваемого говора в контексте истории его формирования, которая приходится на эпоху позднего Средневековья. В европейской истории это XIV-XV вв., при том, что сторонники французской теории «долгого Средневековья» предлагают в качестве завершения эпохи даже конец XVIII века [11, c. 36].

Именно на позднее Средневековье, в принципе, приходится связываемый с экспансией Тимура распад (северо) кавказской тюркской общности кумыкского и карачаево-балкарского языков, который относится к концу XIV - началу XV в. [15, с. 732, рис. 3, 736]. Ранее, в конце XIV в., часть кумыков - будущих носителей терского диалекта - уходит в связи с этим в Крым [1, с. 91-95] из области Борган-Маджар, где находился в XIII-XVI веках золотоордынский город Маджар (ныне г. Буденновск Ставропольского края), известный кумыкской исторической традиции еще в раннем Средневековье. И только в золотоордынский (вторая половина XIII - начало XVI в.) период, но не раньше, как это обычно полагают, имеет место окончательная кыпчакизация кумыкского, как и других булгарских (куманских) языков Крыма, Северного Кавказа и Дагестана [4, с. 86, 171]. Не случайно еще в 1926 г. Бекир Чобанзаде отмечал близость кумыкского «наречия к балкаро-карачайскому и северо-крымскому наречиям тюрко-татар», указывая при этом на то, что такой выдающийся памятник тюркской [кыпчакско-куманской] письменности XIV в., как «Кодекс Куманикус», является, по всей вероятности, историческим памятником именно этой группы» [19, с. 131-132].

Причем к 1502 г., ко времени падения Большой Орды, государство кумыков ('Къумукъ гьакимиет'), называвшееся с XVI в. 'Вилайат Дагестан', включало в свой состав пространство от реки Баксан (при том, что одноименное общество выплачивало ясак кумыкскому шамхалу Будаю I, сыну другого кумыкского правителя-шамхала Умал-Мухаммада, который погиб в 1567 г. при попытке воспрепятствовать сооружению крепости русских в устье р. Сунжи [18]) до Дербента. В отношении вассалитета к нему находились другие кумыкские государственные образования: Тюмен в низовьях Терека и Кумы (по ее течению на месте нынешнего Буденновска был расположен г. Маджар - см. выле) с южными границами до р. Сулак в XVв. (причем кумыки, надо полагать, кизлярцы, были известны еще с XV-XVI в. в городе Малая Тюмень, находившемся на месте нынешнего Моздока [20, с. 32-33], в районе которого они проживают до настоящего времени в с. Кизляр - см. в предшествующем изложении); Кайтаг, который располагался между Дербентом и средневековым кумыкским городом Бойнак (нынешний Избербаш), в то время как Брагунское ханство (Бораган) находилось ко времени вторжения Тимура между Беш-Тау, или Беш-Дагом (Пятигорьем), и средним течением Терека [17, с. 124].

Такой была историческая область прежнего расселения носителей кизлярского говора терского кумыкского диалекта. Они вместе с тюменами и гуенами [2] могут быть отнесены к числу древнейших кумыкских равнинных субэтносов, занимавших в рассматриваемое время западную часть области исторического расселения кумыков. И в их (кизлярцев) говоре не могли не отразиться, как будет показано в последующем изложении, те языковые (лексические и лексико-фонетические) черты, которые свидетельствуют об этом.

Как известно, для установления степени близости тех или иных языков или диалектов одного языка обычно используется базисная лексика, состав которой предполагает ориентацию на известные списки Сводеша, С.А. Старостина, С.Е. Яхонтова, вклю-

62 Вестник Дагестанского государственного университета. Серия 2. Гуманитарные науки. 2018. Том 33. Вып. 3 
Гусейнов Г.-Р.А.-К. Лексические особенности кизлярского говора терского диалекта кумыкского языка в ареальном и историко-этимологическом контексте позднесредневековой эпохи

чающие от 35 до 215 слов. Вместе с тем, как уже было отмечено кумыковедами, которые в той или иной мере занимались изучением рассматриваемого говора, к анализу привлекалась главным образом лексика периферийного характера.

Несколько лет тому назад под патронажем автора статьи и при активном участии известного местного краеведа Саида Ярбаша, памяти которого посвящается данная статья, учителями кумыкского языка и литературы двух средних школ с. Кизляр (Северная Осетия - Алания) была осуществлена выборка лексики рассматриваемого говора на основе 1300-словного списка Института эволюционной антропологии имени Макса Планка (г. Лейпциг). Было выявлено порядка 90 словесных форм, неизвестных кумыкскому литературному языку, среди которых были обнаружены и отдельные элементы, отражающие базисную лексику [5].

Показательно, что произведенный автором последующий этимологический анализ только части вышеупомянутой лексики позволил в дальнейшем установить словесные единицы, относящиеся к древнейшему праалтайскому (гъакгоьв 'безумный') и древнему булгаро-хазарско-караимскому, включая ареально крымский (караимский), т. е. эпохи Хазарского каганата (лапур болуп акъмакъ 'течь, литься потоком', къотан 'конюшня, стойло’) хронологическим уровням. Другие факты свидетельствуют о соответствующем времени проживания на Восточном Кавказе предков нынешних кумыковкизлярцев, ареал обитания которых мог включать и прикаспийский регион, как о том говорит, помимо приведенных выше исторических данных, название паруса (гемени ел кетени), присущее лишь данному говору. Обнаружены лексические формы, связанные как со смежным западнотюркским (кяхыт 'бумага', отложившееся и в вайнахских языках и диалектах, озек 'остров', гевек 'перхоть', сувдан янмакъ 'жажда', присущие огузским языкам), так и восточнотюркским, преимущественно кыпчакским (киш (къара) 'поздний', къачырмакъ (гьайван) 'совокупляться', сунгумек 'нырять') ареалами, несмотря на расположение в крайней западной части нынешнего распространения кумыкского языка [6].

Эта особенность говорит о достаточно давней истории пребывания носителей данного говора не только на Северо-Восточном, но и Центральном, как было показано в предшествующем изложении, Кавказе. О более тесной связи данного говора с кыпчакскими языками свидетельствуют сравнительно многочисленные лексические сходства с ногайским языком. Возникновение этих сходств относится, надо полагать, к той же позднесредневековой, точнее, постзолотоордынской эпохе, когда в регионе появились носители указанного языка.

Ожидаемым оказалось, что говор имеет несколько большую близость к брагунскому говору терского диалекта, но, с другой стороны, обращает на себя внимание то, что аналогичный совокупный уровень близости обоих терских говоров обнаруживается, как было уже отмечено автором [7, с. 87], в отношении говоров южнокумыкских подгорного и кайтагского диалектов, ареально не смежных с терскими говорами (то есть «через голову» хасавюртовского и буйнакского диалектов, легших в основу кумыкского литературного языка, что указывает на значительную древность соответствующих связей). Было также высказано предположение, что специфические, неизвестные кумыкскому литературному языку русизмы данного говора примерно того же возраста, что и ногайские элементы [6].

Сравнительно недавно в одной из наших публикаций текущего года был рассмотрен в ареальном и историческом аспектах и вокализм данного кизлярского говора. Некоторые результаты его анализа, например, лабиализация [и, ы], частично отмечаются в подгорном и кайтагском диалектах, как и депалатализащия лабиализованных гласных, 
Гусейнов Г.-Р.А.-К. Лексические особенности кизлярского говора терского диалекта кумыкского языка в ареальном и историко-этимологическом контексте позднесредневековой эпохи

также присущая кайтагскому и подгорному диалектам и характерная для терского диалекта в целом. Кроме того, в терском диалекте, особенно в кизлярском говоре, в наибольшей степени распространена делабиализащия широких и узких гласных, частично встречающаяся в некоторых говорах хасавюртовского диалекта. Она известна в вышеупомянутых кайтагском и подгорном диалектах, что объясняется неразвитостью в них губных передних [оь] и [уь] и ограниченным их употреблением, по всей видимости, вышеупомянутой делабиализащией. Считается, что лабиализация и делабиализация носят ареальный характер и поддерживаются территориально близкими говорами карачаево-балкарского, ногайского и азербайджанского языков [см. 8]. Вместе с тем факты лексической близости кизлярского говора, кайтагского и подгорного диалектов, отмеченные в предшествующем изложении, носят ареальный характер, позволяют и могут быть обусловлены более общими причинами исторического характера, анализ которых не входит в задачи настоящего исследования.

Данное обстоятельство может быть объяснено не только уже установленной миграцией его носителей в Кайтаг [7, с. 87], куда ушли жители кумыкского Тюменского крым-шамхальства (см. выше) после его включения в состав Русского государства в 1594 г., через Засулакскую Кумыкию, и далее на юг, в кумыкское кайтагское с. Башлы [9], где основали с. Тюменлер (т. е. тюменцы) [7], но и гораздо более древними и обширными ареальными пределами проживания их предков барсил на Северном Кавказе и Дагестане. Изучение этого аспекта древнейшей языковой истории носителей рассматриваемого говора, отдельные лексические факты которого уже были отмечены в статье (праалтайское гьакгоьв 'безумный' и древнее булгаро-хазарско-караимское эпохи Хазарского каганата лапур болуп акъмакъ 'течь, литься потоком', къотан 'конюшня, стойло’), составит цель дальнейших исследований.

\section{Литература}

1. Алиев К.М. Дорогою тысячелетий: кумыки и их этнородственные связи. - Махачкала, 2004. - 127 с.

2. Алиев К.M. Кумыкские гуены и тюмены (к этнической истории Засулакской Кумыкии позднезолотоордынского периода (XV-XVIII вв.) // Материалы Международной научной конференции «Султан-Махмуд и его наследники в дагестанском историческом процессе (XV-XVIII вв.)». - Махачкала, 2011. - С. 106-121.

3. Гаджсиахмедов Т.И. Названия частей тела человека в диалектной системе кумыкского языка // Вестник Дагестанского государственного университета. Cер. 2: Гуманитарные науки. - 2017. - Т. 32, вып. 4. - С. 34-39.

4. Гусейнов Г.-Р.А.-К. История древних и средневековых взаимоотношений языков народов Северо-Восточного Кавказа и Дагестана с русским языком. - Махачкала, 2010. -214 c.

5. Гусейнов Г.-Р.А.-К., Магометова А.Ш., Хажалиева И.З., Шамурзаева Р.Г. Лексика кизлярского говора терского диалекта, неизвестная кумыкскому литературному языку // Записки молодого лингвиста. - Махачкала, 2015. - С. 134-139.

6. Гусейнов Г.-Р.А.-К. Лексические особенности кизлярского говора терского диалекта кумыкского языка в ареальном освещении // Материалы XVII Всероссийской научной конференции (с международным участием) «Актуальные проблемы диалектологии языков народов России». - Уфа, 2017. - С. 81-84.

7. Гусейнов Г.-Р.А.-К. Лексические и некоторые фонетические особенности кизлярского говора терского диалекта кумыкского языка в ареальном и историко- 
Гусейнов Г.-Р.А.-К. Лексические особенности кизлярского говора терского диалекта кумыкского языка в ареальном и историко-этимологическом контексте позднесредневековой эпохи

этимологическом контексте // Вестник Дагестанского государственного университета. Cep. 2: Гуманитарные науки. - 2018.- Т. 33, вып. 2. - С. 84-89.

8. Гусейнов Г.-Р.А.-К. Вокализм кизлярского говора терского кумыкского диалекта в ареальном и историческом аспектах // Материалы XVIII Всероссийской научной конференции (с международным участием) «Актуальные проблемы диалектологии языков народов России». - Уфа, 2018.- С. 43-46.

9. Идрисов Ю. Кавказская Тюмень между Волгой и Кавказом: возникновение и гибель государства // Средневековые тюрко-татарские государства. - Казань, 2014. Вып. 6. - С. 80-84.

10. Керимов И.А. Очерки кумыкской диалектологии. - Махачкала: Дагучпедгиз, 1967. - $155 \mathrm{c}$. $440 \mathrm{c}$.

11. Ле Гофф Ж. Средневековый мир воображаемого. - М.: Прогресс, 2001. -

12. Ольмесов Н.X. Бораганский говор и его место в системе диалектов кумыкского языка. - Махачкала: Изд-во ДГУ, 1994. - 142 с.

13. Ольмесов Н.X. Сравнительно-историческое исследование диалектной системы кумыкского языка: автореф. дис. ... докт. филол. н. - Казань, 1996. - 68 с.

14. Саидов A.M. Становление и развитие кумыкской диалектологии // Балтийский гуманитарный журнал. - Калининград, 2017. - Т. 6, № 4 (21). - С. 175-177. $767 \mathrm{c}$.

15. Сравнительно-историческая грамматика тюркских языков. - М.: Наука, 2002. -

16. Хангишиев Д.М. Къумукъ диалектологиясы. Къысгача курс. - Махачкала, 1989. $-81 \mathrm{c}$.

17. Ханмурзаев И.И., Идрисов Ю.М. Проблема образования средневекового кумыкского государства Шаухальство в контексте политического наследия Улуса Джучи на Северном Кавказе // Золотоордынская цивилизация. - Казань, 2008. - Вып. 1. C. $122-136$.

18. Чомаев А.Б. К вопросу датировки исторических событий, получивших отражение в карачаево-балкарском фольклоре // Известия Карачаевского научно-исследовательского института. - Черкесск: ИКО «Аланский Эрмитаж». - 2015. - Вып. 11. C. 39-43 // URL: http:// ilmu.su/k-voprosu-datirovki-istoricheskih-sobytij-poluchivshihotrazhenie-v-karachaevo-balkarskom-folklore/.

19. Чобанзаде Б.В. Предварительное сообщение о кумыкском наречии (Доклад, зачитанный на заседании Лингвистической комиссии Общества 20.11.1925 г.) // Известия Общества обследования и изучения Азербайджана. - Баку, 1926. - № 1. - С. 113-132.

20. Ярбаш С., Идрисов Ю. Новые сведения о кумыках Северной Осетии // Кумыкский архив. - Махачкала: Абусупиян, 2018. - С. 29-33.

Поступила в редакцию 10 октября 2018 г. 
UDC $811.351 .14 / 16$

DOI: $10.21779 / 2542-0313-2018-33-3-61-66$

\title{
Lexical features of the Kizlyar dialect of a Terek dialect of the Kumyk language in the areal and historical and etymological context of late Medieval Era
}

\author{
G.-R.A.-K. Guseinov \\ Dagestan State University; Russia, 367001, Makhachkala, M. Gadzhiev st., 43a; \\ garun48@mail.ru
}

The article continues the cycle of the author's researches in recent years, devoted to introduction to scientific turkological turnover of materials isolated (the settlements of Kizlyar, Predgornoje and Small Malgobek of the Mozdok region of Republic of North Ossetia - Alania) the Kizlyar dialect of Terek dialect of the Kumyk language. It was almost not studied until recently when the author of the present article addressed to the research this dialect, and the main objective of this publication - consideration of lexical features of this dialect in a wide areal and historical and etymological context. As a result additional linguistic and historical arguments which once again indicate more extensive western areal limits of distribution of the Kumyk language during the considered era were adduced. Their interpretation in the relation to other Kumyk dialects and also attraction of the latest historical data has allowed, first, to specify time of migration of carriers of neighbouring east (Bragun) Terek river dialect, localizable in Chechnya, to the southern Kumyk historic area Kaytag, secondly, - to assume earlier emergence of some lexical features considered at the same time.

Keywords: Kumyk, Karachay-Balkar, Nogay, Kizlyar, Bragun, dialect, areal and historica-etymological context.

Received 10 October, 2018 